\title{
Performance Impact of e-business use in Indonesian Small and Medium Enterprises (SMEs)
}

\author{
NABILA \\ 130119015 \\ Faculty of Business and Economics \\ University of Surabaya
}

\begin{abstract}
Destination : A new business platform is a must for companies that are disrupting new media technology, especially during the Covid 19 era. However, many incumbent companies are less able to keep up with changing business trends. Anticipate all changes in the competitive climate in the digital era in carrying out the company transformation program along with the implementation of good corporate governance values to avoid oral hazards and a greater risk of failure. proposes an integrated framework that investigates interrelationships between contextual factors that influence e-business use and consequently its impact on enterprise performance among small and medium enterprises (SMEs).
\end{abstract}

\section{Keywords :}

Digital Platform, SMEs, e-business, Use Impact, Government Intervention 


\section{INTRODUCTION}

Small and medium enterprises (SMEs) are the cornerstone of many economies. As a group, SMEs account for $95 \%$ of the world's enterprises and absorbs $60 \%$ of employment according to recent data from the International Finance Corporation (International Finance Corporation, 2011). The economic effects are typically more notable in developing countries such as Indonesia where SMEs provide as much as $99 \%$ of the available jobs (Ministry of Cooperatives and SMEs, 2013). In the increasingly global and digital economy, SMEs are expected to employ e-business to stay relevant and more importantly ahead of the competition. While consumers in general seem to have embraced e-business to a great extent, SMEs are not necessarily so.

In the case of Indonesia, a country where the Internet penetration reaches $64,8 \%$ of country's total population and the average citizen owns more than one mobile phone (APJII, 2019; International Telecommunication Union, 2018), the adoption of e-business among SMEs was low at $9 \%$ as of the year of 2019, according to Indonesian Ministry of Communications and Informatics (Deviyana, 2019). In its publication, the Central Bureau of Statistics of the Republic of Indonesia (Indonesian: Badan Pusat Statistik / BPS) explained that the Indonesian economy experienced deflation of $0.1 \%$ in July 2020.

\section{PROBLEMS}

Indonesian economy experienced deflation of $0.1 \%$ in July 2020. The food, beverage, and tobacco group experienced deflation of $0.79 \%$ and contributed to deflation of $0.19 \%$. Foodstuffs that contributed to deflation included shallots, broiled chicken, rice, garlic, cayenne pepper and sugar. This deflation in food and beverages indicates a decline in demand for food. The decline in demand for food was correlated with a decrease in the exchange rate of agricultural food crops by $0.25 \%$, or to be 110.17 . Likewise, there was a decrease in the exchange rate of horticultural agricultural products by $0.74 \%$, or to be 99.77 ; including deflation in the Household Consumption Index of $0.13 \%$. In terms of the contribution of public expenditure, it appears that the $20 \%$ group (upper class) reaches $45.49 \%$ of the total national consumption, the $40 \%$ group (middle class) contributes $36.78 \%$, and the $40 \%$ group (lower class) only contributes $17 \%$. 


\section{REVIEW}

In this section, we review related research that serves as a foundation of this study, including factors that play a role in influencing the use e-business and subsequent enterprise performance among SMEs. Due to their strategic role in development, MSMEs must continue to be developed. There should be mutual reinforcement between MSMEs and large businesses in the context of equitable distribution and realizing the greatest possible prosperity for the entire community. The government is obliged to direct, guide, protect and foster the business climate.

\section{RESEARCH}

This research is a qualitative research with the aim to find out the development of MSMEs in Indonesia after being affected by the Covid-19 pandemic, a decrease in people's purchasing power and an economic recession. The Covid-19 outbreak had a negative impact on $84.7 \%$ of MSMEs, average income fell significantly by $53 \%$, and around $72 \%$ of MSMEs experienced a decline in income of more than 40\%. MSMEs have a very big role in the Indonesian economy. The facts show that 62.4 million MSMEs in Indonesia are able to absorb $97 \%$ of the workforce, contribute to Gross Domestic Product around 61\%, and contribute to exports $14 \%$. (BPS, 2020)

\section{DISCUSSION}

Based on the current developing conditions, the government should focus more on controlling the Covid-19 pandemic so that confirmed cases can decrease and give confidence to the public, especially the middle and upper class, to shop again and restore consumption, given that Indonesia's economic growth is still supported by household consumption expenditures. A stimulus for social protection and assistance to businesses can drive consumption growth. The growing consumption and purchasing power of the people will prevent Indonesia from an economic recession, considering that economic recovery with the graph V scenario is still possible, especially since the budget provided by the government is quite large in 2020 or IDR 203.9 trillion for social protection during the handling of Covid19. However, it should be understood that the economic recovery will not be evenly distributed in all sectors. 


\section{CONCLUSION}

Digitalization has proven to be able to open up inclusivity and electronification in Indonesia. Digitalization and electronification of services can actually support economic recovery programs, such as the distribution of social assistance and financing for MSMEs. Electronification makes the distribution of social assistance more targeted and timely, which in turn will have an impact on improving domestic consumption as the main support for national economic growth. Digitalization of payment and financing systems has the potential to open financial access to 62.9 million MSMEs and 51\% of the population (91.3 million people) who have not been reached by banking access.

MSMEs need to be continuously encouraged so that they can be integrated into the national production system or global supply chain. MSMEs must be able to work on local advantages to produce special products so that they can be more competitive in both the domestic market and the international market. 


\section{BIBLIOGRAPHY}

Tayibnapis, Ahmad Zafrullahand Wuryaningsih, Lucia Endang and Gora, Radita (2020) Medium, Small and Medium Enterprises and Digital Platforms. South Asian Journal of Social Studies and Economics 10(2): 10-19, 2021; Article no.SAJSSE.65860 ISSN: 2581-821X

Panca O, Hadi Putra, Harry B. Santoso (2020)

Contextual factors and performance impact of e-business use in Indonesian small and medium enterprises (SMEs). Volume 6, Issue 3, March 2020, e03568 